\section{Time in Renaissance Philosophy}

Olivier Dubouclez

Department of philosophy, University of Liège, Liège, Belgium

\section{Abstract}

As a central dimension of the Human experience, the conception of time has undergone deep transformations during the Renaissance period, in relationship with global evolutions in European arts, sciences, and metaphysics. The Aristotelian definition of time as "a number of motion in respect to before and after" was challenged to open the way to an ontological determination of time, independent from motion and connected to the divine structure of beings in the universe. From Ficino to most innovative thinkers like Telesio, Patrizi. Bruno in particular introduced a relativistic perspective and showed that we should rather speak of a multiplicity of times. The reflection on the difference between time and duration has been another technical issue developed by Renaissance thinkers: since time was no more referred to the Ptolemaic cosmos, the concept of duration was used to designate the internal time of things and existing beings, as Suarez makes clear at the beginning of seventeenth century. This idea of time as an inner reality also had important applications in the field of literature and moral philosophy, as we see for instance in
Shakespeare and Montaigne. Although Modern Philosophers like Descartes or Pascal seem to break with the scholastic approach of time, it is interesting to note that the pre-Newtonian concept of "absolute time" is rooted in Renaissance theories of time and the development of Copernicanism leading to the construction of a new reference frame, where the Suarezian "imaginary time" plays a central role.

\section{Heritage and Rupture with the Tradition}

More than in any other period in the history of thought, the complexity and the fallibility of the philosophical definitions of time have been the object of close scrutiny during the Renaissance. While most of medieval thinkers concentrate on Aristotle's Physics IV, 10-14, and tackle obscurities or objections that can be raised about the Aristotelian conception of time, the rise of humanist scholarship combined with a renewed access to ancient doctrines (Neoplatonism, but also Epicureanism, Stoicism, or Averroism) broadens the field of available references and leads Renaissance thinkers to question the authority of the Aristotelian framework. Far from disappearing outright, the medieval language of time maintains itself in those debates: the distinction between the three modes of duration, eternity (ceternitas), perpetuity (cevum), and time (tempus) as introduced in the course of the thirteenth century by the Summa Halensis, still informs theoretical 
inquiries. But during the Renaissance, the philosophical study of time aims not so much at solving problems of interpretation raised by Aristotle's texts as at helping to build a global and coherent view of the cosmos. Insofar as Neoplatonism provides a system of thought where time is primarily referred to eternity and motion is secondary to time itself, Aristotle's canonical definition of time as "a number of motion in respect to before and after" is indeed replaced by an alternative ontology. Marsilo Ficino (1433-1499) is the prominent figure of such a transformation: according to him, time must be regarded as something of the world soul and, for this reason, it can neither be produced by motion nor be an accident or a property of it. In the Plotinian view that he promotes, time is "life" itself as it flows from the activity of the world soul and is tied up to eternity through a hierarchy of derivative forms of being. Ficino's philosophical program is coupled with a religious agenda, building a new Christianized cosmology and also, to this extent, facing the difficulties of compromise - as one can see from the uneasy combination of the linear conception of Christian time with the cyclical model exposed in Plato's Timoeus (Prins 2014).

That time is a moving image of eternity does not mean, however, that it is a mere shadow or appearance. In the Neoplatonic view, it pertains to the very structure of things as they are ordered and divinely produced. Neoplatonic thinkers are eager to underline what may be the deepest flaw of Aristotelianism, namely the confusion between the knowledge of time (how do we come to know it?) and the ontological perspective (what is time and what is required for it to be?). Indeed, that the perception of time implies the existence of motion does not mean, as Aristotelians contend, that the very existence of time actually depends on motion, as Pico della Mirandola (1463-1494) already suggests (Schmitt 1967). Time is prior to motion according to Telesio (1509-1588), who sees it as an independent being having its existence in oneself and being like a receptacle of natural movements (Schumann 2004). Along with Bernardino Telesio and Francesco Patrizi
(1529-1597), Giordano Bruno (1548-1600) develops a critical approach to Aristotle within a whole system of thought which, notwithstanding a few theoretical elements borrowed to the Physics, has no other goal than taking over the Aristotelian paradigm. Bruno's achievements are probably the most impressive as regards the theory of time. He views time as a species of duration and accordingly contends that it should not be seen as ontologically dependent on motion: it would be more correct to say that motion is related to time since we know of duration by looking at things as they move or change (Hutton 1977). But Bruno is also the heir of the Copernican revolution and for this reason he considers that the very spectacle of heavens cannot be the measure of time any longer. The destruction of the Ptolemaic cosmology implies to break with time as referred to the perfection of the primum mobile and to favor instead an earthly reference, one point of view among an infinite variety of others (Seidengart 2015). According to Bruno's vision, there are many times rather than one time, each local time being one "age," that is to say, one aspect of eternity. The Platonic dualism between time and eternity plays an important role here: while "eternity" is seen as the genus of time or absolute duration, "age" is a particular fragment of it which is determined in connection to things in motion. Copernic himself did not feel the need of any updated conception of time, but he clearly provides a backdrop for understanding Bruno's theory as well as future attempts to think of time as different from motion and from celestial motion in particular (Blumenberg 1973; Daniel 1981).

But that some prominent Renaissance thinkers have chosen the tenuous bond of time with motion as a common target should not preclude another fact: namely, that Aristotle's authority has been defended throughout the Renaissance period. At the beginning of the seventeenth century, the Fathers of Coimbra whose influence in European universities is well-known continue to defend the idea that motion must be prior to time as what produces time and to focus on Aristotelian issues. 


\section{Innovative and Original Aspects}

Now, does the autonomy of time as a concept mean that time is something real? For instance, can we hold time as an immaterial entity that flows without any reference to natural things?

The problem of the reality of time is all the more vivid that late medieval authors have put into question the idea that time might be an independent being. William Ockham's razor but also Duns Scotus' understanding of "existence" have led to the claim that time does not exist as something distinct from the existence of movement and, as a consequence, that such a distinction has no necessity, existence and intrinsic duration of a thing being one and the same. This is of course a strongly anti-Neoplatonic allegation: if time is not a property of moving things, it surely cannot be a property of an unchanging thing as eternity; it must be intrinsic to things themselves and therefore identical with them. Moreover time is not the right word if we want to speak of what is really passing by: we should rather speak of "duration." Such a de-realization of time where time is made a property of the individual beings can be traced back to the Middle Ages, but it is given more influence at the end of the Renaissance, philosophers considering "not so much the relation between a thing and time, than the intrinsic duration of the thing itself" (Porro 1996). Following this trend, Francisco Suarez (1548-1617) has defended the view that duration is distinct from existence only "ratione" in his Disputatio 50, another anti-Aristotelian idea that has been challenged by the Fathers of Coimbra (Carvalho 2001). Of course, if duration is intrinsic to things, it is a problem to explain how time can be measured. Suarez maintains this possibility with the notion of an imaginary succession conceived as homogeneous and infinite to be applied to the enduring of a thing. What he calls "extrinsic time" designates time as measured by the reference to celestial movement and it is to be distinguished from the intrinsic account of time (Daniel 1981).

But when questioning the reality of time, one should not overlook the psychological side of the problem as it has developed not only in philosophy (Cassirer 1927) but also in the Renaissance literary tradition in order to explain how we think of time, but also how we think and live in time (Edwards 2013). An important tendency in literature and arts leads authors to elaborate the personal experience of passage and mutability through "time-centered fictions" as we can see in Shakespeare who, as he is dependent on the Augustinian representation of time, holds time as being both a destroyer and revealer of truth (Hill 1997). This evolution, from the religious notion of the transience of life to the secular idea that temporal passage is a necessary condition of human experience, find another striking expression in Montaigne's Essays who, better than any other philosopher, underscores that time is the most fundamental dimension of the self and the thinking of time must be linked with the very feeling of its successive flow.

Nevertheless, the problem remains to determine how human thought relates to time and this is quite a polemical matter in the field of Renaissance debates. Indeed, medieval authors, while theorizing the notion of a spiritual time proper to spiritual substances and distinct from the time of natural substances, have constantly refused to apply it to human souls (Steel 2001; Blum 2007). When Ficino speaks of "mora," a notion close to the medieval concept of discrete duration, he wants to preserve the human soul's immortality and he accordingly endows it with pure spirituality. The idea of a connection between time and the soul is not new; it can be found in Aristotle's Physics itself (Physics IV, 14). But along with Averroes' qualification of time as a minddependent attribute, reduced to the mental action of numbering, it has received wider consideration, especially in Italy during the course of the sixteenth century. Some followers of Alexander of Aphrodisias have attempted to think of intellection as a temporal reality, produced by a soul immersed within the natural duration of things. To this purpose, from Simone Porzio to Francesco Piccolomini, the Aristotelian concept of "act" is applied to human thought and sustained by a renewed description of the psychology of faculties and their mutual relationships. In such a context, time is conceived as an aspect of acts, either 
mental, corporeal, or involving both mind and body, such as sensation, intellection, or judgment. Because these acts occupy a very short lapse of time or are said to be "instantaneous," they are sometimes considered to be different components of one temporal activity rather than being autonomous operations or events (Dubouclez 2015). The old model connecting intellectual activity with time through the means of imagination, as it appears for instance in Thomas Aquinas, is challenged within this materialistic vision of man. Duration is no more a simple attribute of existence, but a real passage implying materiality and mortality.

\section{Impact and Legacy}

The legacy of the Renaissance conceptions of time must be appreciated in the light of the historiographical problem of continuity and discontinuity from Renaissance to modern times. To this respect, we might say that the Renaissance explanation of time, both Aristotelian and Neoplatonic, has mixed outcomes.

Indeed, we find in Descartes and Pascal a common attitude, namely the rejection of all philosophical definitions of time, vividly opposing the word-by-word method of explanation to be found in scholastic textbooks and even the very project of inquiring on time. Descartes in particular holds that duration and time are notions clear by themselves and that philosophical definitions obscure them and produce artificial difficulties. In the meantime, Descartes develops important reflections on the matter of time to be connected with late scholastic discussions, as debates around the doctrine of the "continuous creation" indicate. Pierre Gassendi (1592-1655) refuses the Cartesian idea that time is made of divisible parts or instants and also the conception of an intrinsic time proper to enduring things and especially to the ego; he has indeed a realistic conception of time as a global flow, while Descartes' distinction between "duratio" and "tempus" (Principles of Philosophy, I, 55 and 57) is close to the distinction between "internal time" and "external time" in philosophical textbooks (Edwards 2013). But there are other aspects of the Cartesian doctrine that look hard to reconcile with the Aristotelian views: for instance, when Descartes replies to Arnauld that the same kind of "succession" is to be found in the thinking substance as in natural things, he has a unified conception of time as flowing in the same manner in natural substances and in the self (Solère 1997). One might see Descartes' theory of time as "temporal dualism" articulating a physical notion and a psychological notion of it, time being both a reality to be divided into parts and an innate idea and attribute of the thinking substance, announcing the Kantian notion of "a priori form" in the Critique of Pure Reason (Waller 2014).

This is obviously one of the most fruitful aspects of late Renaissance conceptions of time, namely the prevalence of duration over the Aristotelian cosmological approach, leading to the radical individuation of time as we see in van Helmont, who conceives of time as a biological and indivisible principle (Debus 1977). And it should be underlined that such a conception has also cosmological consequences of its own. Indeed, within another tradition that Renaissance thinkers are supposed to have initiated, namely the pre-newtonian concept of "absolute time," imagination is attributed a central role in the building of such a temporal reference frame. Renaissance scholars have shown that the "absolutization" of time has to be related to the development of Copernicanism, providing a response to the immobilization of the celestial spheres which is the consequence of the downfall of the Ptolemaic cosmology (Ariotti 1973), but also to the Suarezian notion of "imaginary time" as a means of measuring the intrinsic time or duration of things, a conception that will be prolonged by Gassendi and Gassendists (Bexley 2011).

\section{Cross-References}
Aristotelianism
- Astronomy
- Bruno, Giordano
- Castellani, Giulio 
- Copernicanism

$\checkmark$ Copernicus, Nicolaus

- Cosmology

- Ficino, Marsilo

- Generation

- Intellect

- Neoplatonism

- Nicholas of Cusa

- Suárez, Francisco

\section{References}

\section{Secondary Literature}

Ariotti, Piero. 1973. Toward absolute time: The undermining and refutation of the Aristotelian concept of time in the sixteenth and seventeenth centuries. Annals of Science 30: 31-50.

Bexley, Emmaline. 2011. Quasi-absolute time in Francisco Suárez's metaphysical disputations. Intellectual History Review 22 (1): 5-22.

Blum, Paul Richard. 2007. The immortality of the soul. In The Cambridge companion to renaissance philosophy, ed. James Hankins, 211-233. Cambridge: Cambridge University Press.

Blumenberg, Hans. 1973. Die Kopernikanische Konsequenz für den Zeitbegriff. In The reception of Copernicus' Heliocentric theory, ed. Jerzy Dobrzycki, 57-77. Dordrecht/Boston: Springer.

Carvalho, Mario Santiago de. 2001. The concept of time according to the Coimbra commentaries. In The medieval concept of time: Studies on the scholastic debate and its reception in early modern philosophy, ed. Pasquale Porro, 353-382. Leiden: Brill.

Cassirer, Ernst. 1927. Individuum und Kosmos in der Philosophie der Renaissance. Dordrecht/Leipzig: Teubner.

Daniel, Stephen H. 1981. Seventeenth-century scolastic treatments of time. Journal of the History of Ideas 42 (4): 587-606.
Debus, Allen G. 1977. The chemical philosophy. Paracelsia science and medicine in the sixteenth and seventeenth centuries. Mineola: Dover.

Dubouclez, Olivier. 2015. On the time of the intellect: The interpretation of De Anima 3.6 (430b 7-20) in renaissance and early modern Italian philosophy. Early Science and Medicine 20: 1-26.

Edwards, Michael. 2013. Time and the science of the soul in early modern philosophy. Leiden/Boston: Brill.

Hill, John Spencer. 1997. Infinity, faith and time. Christian humanism and renaissance literature. Montreal/Kingston: McGill-Queen's University Press.

Hutton, Sarah. 1977. Some renaissance critiques of Aristotle's theory of time. Annals of Science 34 (4): 345-363.

Schumann, Karl. 2004. Zur Entstehung des neuzeitlichen Zeitbegriffs: Telesio, Patrizi, Gassendi. Philosophia Naturalis 25: 37-64.

Porro, Pasquale. 1996. Forme e modelli di durata nel pensiero medievale: l'aevum, il tempo discreto, la categoria "quando". Leuven: Leuven University Press.

Prins, Jacomien. 2014. Echoes of an invisible world. Marsilio Ficino and Francesco Patrizi on cosmic order and music theory. Leiden: Brill.

Schmitt, Charles B. 1967. Gianfrancesco Pico della Mirandola (1469-1533) and his critique of Aristotle. The Hague: Martinus Nijhoff.

Seidengart. 2015. Dieu, l'univers et la science infinite. Penser l'infinité cosmique à l'aube de la science classique. Paris: Albin Michel.

Solère, Jean-Luc. 1997. Descartes et les discussions médiévales sur le temps. In Descartes et le Moyen Age, ed. Joël Biard and Roshdi Rashed. Paris: Vrin.

Steel, Carlos. 2001. The neoplatonic doctrine of time and eternity and its influence on medieval philosophy. In The medieval concept of time: Studies on the scholastic debate and its reception in early modern philosophy, ed. Pasquale Porro, 3-31. Leiden: Brill.

Waller, Rebecca Lloyd. 2014. Descartes' temporal dualism. London: Lexington Books. 